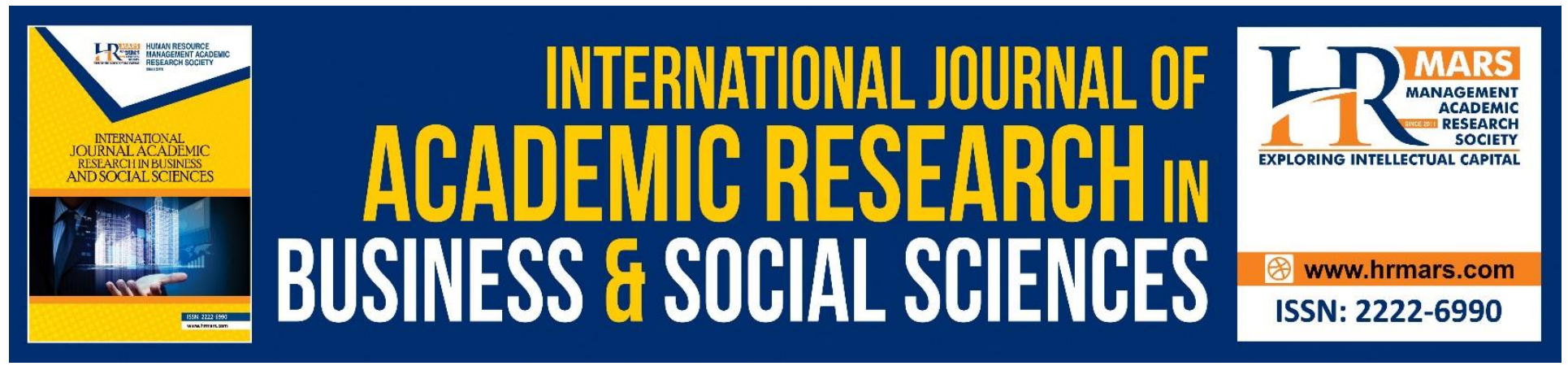

\title{
The Effectiveness of Nada's Career Counseling Model towards Career Maturity and Self-Concept of Former Drug Addicts: A Qualitative Study
}

Amin Al Haadi Bin Shafie, Hishamuddin Bin Abdul Wahab, Mohd Khairul Anuar Bin Rahimi, Nurhafizah Binti Mohd Sukor, Siti Nubailah Binti Mohd Yusof, Nurhafizah Binti Mohamad Yasin, Nurul Ashikin Binti Ahmat Miskam

To Link this Article: http://dx.doi.org/10.6007/JJARBSS/v9-i6/5943 DOI: $10.6007 /$ IJARBSS/v9-i6/5943

Received: 02 April 2019, Revised: 23 May 2019, Accepted: 06 June 2019

Published Online: 29 June 2019

In-Text Citation: (Shafie et al., 2019)

To Cite this Article: Shafie, A. A. H. Bin, Wahab, H. B. A., Rahimi, M. K. A. Bin, Sukor, N. B., Mohd, S. N. B. M. Y., Yasin, N. B. M., \& Miskam, N. A. B. A. (2019). The Effectiveness of Nada's Career Counseling Model towards Career Maturity and Self-Concept of Former Drug Addicts: A Qualitative Study. International Journal of Academic Research in Business and Social Sciences, 9(6), 229-246.

Copyright: (c) 2019 The Author(s)

Published by Human Resource Management Academic Research Society (www.hrmars.com)

This article is published under the Creative Commons Attribution (CC BY 4.0) license. Anyone may reproduce, distribute, translate and create derivative works of this article (for both commercial and non-commercial purposes), subject to full attribution to the original publication and authors. The full terms of this license may be seen at: http://creativecommons.org/licences/by/4.0/legalcode

Vol. 9, No. 6, 2019, Pg. 229 - 246

http://hrmars.com/index.php/pages/detail/IJARBSS

JOURNAL HOMEPAGE

Full Terms \& Conditions of access and use can be found at http://hrmars.com/index.php/pages/detail/publication-ethics 


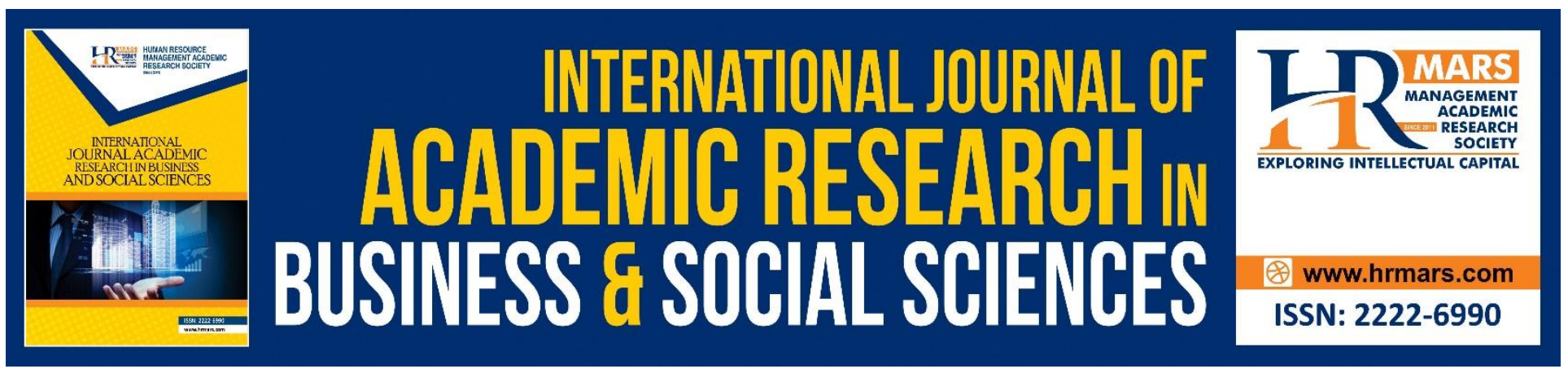

\title{
The Effectiveness of Nada's Career Counseling Model towards Career Maturity and Self-Concept of Former Drug Addicts: A Qualitative Study
}

\author{
Amin Al Haadi Bin Shafie ${ }^{1,3}$, Hishamuddin Bin Abdul Wahab², Mohd \\ Khairul Anuar Bin Rahimi ${ }^{1,3}$, Nurhafizah Binti Mohd Sukor ${ }^{3}$, Siti \\ Nubailah Binti Mohd Yusof ${ }^{3}$, Nurhafizah Binti Mohamad Yasin ${ }^{1}$, \\ Nurul Ashikin Binti Ahmat Miskam ${ }^{1}$ \\ ${ }^{1}$ Asian Centre of Research on Drug Abuse (ACREDA) Universiti Sains Islam Malaysia Bandar Baru \\ Nilai, 71800, Nilai Negeri Sembilan, Malaysia \\ ${ }^{2}$ Faculty of Science and Technology Universiti Sains Islam Malaysia Bandar Baru Nilai, 71800, Nilai \\ Negeri Sembilan, Malaysia \\ ${ }^{3}$ Faculty of Leadership \& Management, Universiti Sains Islam Malaysia, Bandar Baru Nilai, 71800, \\ Nilai Negeri Sembilan, Malaysia
}

\begin{abstract}
Chronic unemployment is seen to be one of the most contributing factors of relapse among drug addicts in Malaysia. Many interventions had been implemented by the government to helps the client with fully abstinent. However, the number of drug addicts can't be deemed to be reduced especially for those who are unemployed. Thus, NADA's Career Counseling Model had been developed to intervened with the unemployment issue among drug addicts to prevent relapse. 25 participants had been involved in this research with the aimed to identify the effectiveness of NADA's Career Counseling Model through a qualitative approach. 10 sessions had been conducted with directed counseling module which emphasized on the self-concept and career maturity of the former drug addicts. Facilitator's observation, semi-structured written interview, and in-depth interview had been considered as the research finding to determine the effectiveness of the Career Counseling Model in enhancing their self-concept and career maturity.
\end{abstract}

Keywords: NADA, Career Counseling Model, Career Maturity, Self-concept, Drug Addicts

Introduction

The relationship between unemployment and substance use continues to be an important point of discussion in both science and politics (Henkel, 2011). Chronic unemployment is common among drug 
addicts and identified as a major contributor to drug relapse (Wong \& Silverman, 2007; Boundy \& Collelo, 2001). This statement had been supported by Satar (2017) which clarify that the rising unemployment rate is among the contributing factor towards drug addiction. Henkel (2011) also stated that the causal relationship between substance use and unemployment continues to be an important feature in research today. In 2016, the National Anti-drugs Agency reported that 30, 844 drug addicts had been involved with drug addiction in Malaysia and most of them were from age 20 years -40 years. These groups of young ages are seen as the asset of the country if their potential is used at the optimum state.

Even though various intervention had been taken by the National Anti-drugs Agency in helping with drug rehabilitation which includes vocational training and apprentice practice, the former drug addicts will have difficulties in getting a suitable career after being released from the rehabilitation center, and not exclusive to confront with the difficulties in preventing relapse. This statement also being supported by Boundy and Collelo (2001) which the researches claimed that unemployment is recognized as a major contributing factor towards the relapse rate, which is turning back to addictive behaviors. Fauziah, Bahaman, Mansor, \& Mohamad Shatar (2012) also clear that most of the former inmates in the rehabilitation center were intimidated to start off living and face the real world to seek jobs that could afford them and their families. McLellan, Lewis, \& O'Brien (2000) mentioned that lacking in vocational skill has been identified as one of the main contributors to the high unemployment rate among former drug addicts, it is a never-ending cycle experienced by most of the former drug addicts. Thus, these show the signs of having proper career planning for former drug addicts to prevent relapse.

Apart from unemployment, Samuels \& Samuels (1974) suggest that low self-concept is a common denominator as a causative factor of drug abuse or relapse. A research had been administered by Samuel \& Samuel (1974) which conclude that low self-esteem can lead a person involved with drug abuse. Super's mentioned in his Career Development Theory that self-concept is significant in determining one's career maturity. 2 elements had been emphasized which are psychology development and the environment structure of socio-economy. Super define selfconcept as the way of a person to define themselves.

In line with that, a career therapy named Career Counseling Model (CCM) had been designed to enhance the vocational skill of the trainees in the rehabilitation center which emphasized on 2 main elements which are career maturity and self-concept. Thus, this study aimed to identify the effectiveness of Career Counseling Model towards the participants

\section{NADA's Career Counseling Model}

The National Anti-Drugs Agency (NADA) is an agency under the purview of The Ministry of Home Affairs that oversees drug-related matters in Malaysia. Being a leading agency in combating drug issues, NADA is committed to providing the best treatment and rehabilitation, prevention, enforcement and supervision for our clients. At the same time, NADA also plays a vital role in realizing the Government's goal of Drug-Free Malaysia. Drug abuse and addiction had always been a global issue that impacted many peoples' lives negatively which includes Malaysia. This issue had escalated since the 1970s that had prompted Malaysia to declare drugs as the "Nation's Number 1 Enemy" to 
INTERNATIONAL JOURNAL OF ACADEMIC RESEARCH IN BUSINESS AND SOCIAL SCIENCES Vol. 9, No. 6, June, 2019, E-ISSN: 2222-6990 (C) 2019 HRMARS

this day. Thus, a Career Counseling Model had been developed with the aimed of intervention to prevent relapse among drug addicts.

This research administered the Career Counseling Model which was adapted from the Career Counseling Model by Magnusson (1995) and Kidd (2007) that had been influenced by Super's Career Development. This model emphasizes on self-concept in the career development of an individual. There are 10 sessions in total within this model. It is consisting of 1 module for ice breaking, 2 modules on self-concept, 6 modules for career maturity and one last session to conduct semi-structured questions and in-depth interview sessions with participants to share their responses. Table 1 shown below visualizes the Modules of Career Counseling Therapy:

Table 1 Modules of Career Counseling Model

\begin{tabular}{|c|c|c|}
\hline $\begin{array}{c}\text { Session } \\
\text { (2 Hours duration) }\end{array}$ & Theme & Activity/Modules \\
\hline 1 & \multirow[t]{3}{*}{ Self-concept } & $\begin{array}{c}\text { Ice breaking - Activity conducted to build } \\
\text { the rapport between the group member } \\
\text { and facilitator }\end{array}$ \\
\hline 2 & & Self-concept activity 1 \\
\hline 3 & & Self-concept activity 2 \\
\hline 4 & \multirow{6}{*}{ Career Maturity } & Career Interest \\
\hline 5 & & Career Maturity \\
\hline 6 & & Decision making \\
\hline 7 & & $\begin{array}{l}\text { Sharing session by the Human Resource } \\
\text { Department of Malaysia 'Jobs Malaysia' }\end{array}$ \\
\hline 8 & & Job preparation \\
\hline 9 & & Action plan \\
\hline 10 & Closing session & $\begin{array}{l}\text { 1. Semi-structured questions for } \\
\text { participants } \\
\text { 2. In-depth interview session with } \\
\text { participants }\end{array}$ \\
\hline
\end{tabular}

\section{Literature Review}

Career therapy is seen as a unique approach and can help those in the process of recovering from drug abuse (Opp,2007). With the objective to further strengthening the rehabilitation treatment for a drug abuse problem, it is very important to shifting the research priority to the need for career intervention among the trainees. Hence, a strong career plan needs to be given to providing a chance for them to enter a more realistic workplace. Career Counseling Model developed with the aimed to prevent relapse among former drug addicts and to help them gained new knowledge and insight for their career planning. There are 2 main elements emphasized which are self-concept and career maturity. 


\section{Self-concept}

Rogers (1961) defines self-concept as the way one thinks and considers himself based on awareness of the advantages and disadvantages and the information received from others. According to Combs and Snygg (1949), self-concept is an indication of self-understanding of individuals and individuals behaving as he sees himself and the behavior shown is either realized or will not give a picture of himself. Individuals with high self-concept are said to be content with themselves and feel themselves to meet their human standards (Rosenberg, 1985).

According to Azizi Yahaya (2005), there are two types of self-concept, which are positive selfconcept and a negative self-concept. Individuals with positive self-concept are often well-served by people around them on this individual factor having social skills and good communication. Additionally, individuals with positive self-concept have more success than failure in their lives. If this individual fails, it will accept it as a challenge to do better in the future. This individual also often feels happy, confident and has a high level of confidence in him in doing something. On the other hand, if the individual has a negative self-concept, the individual relationship with the person around it is also a lack of building relationships and socializing well. This group of persons will be easily offended, too humble and unsure about himself. Additionally, individuals with a negative self-concept will accept failure in a negative way in which they are to blame others, irrational and despairing. Research that had been done by Samuel \& Samuel (1974) proves that a person with low self-concept is having a high tendency to be involved with drug abuse.

\section{Career Maturity}

The core element of CCM is career maturity. Career maturity is the main concept of Super's Life Span Theory which was defined as the readiness of the individuals to make a proper career decision (Super 1953). Career maturity had been defined as the readiness of the individuals to make a proper career decision (Super, 1953). Career maturity relates more to intelligence than to age (Zunker, 2012). Career maturity had been seen as a key factor in ensuring the employment rate of the trainee in the rehabilitation treatment program. Super (1955) describe 5 major components in career maturity which are career planning, readiness to explore, informational competence (includes educational requirements, skill requirements, the types of professions available, job climate, and regulations and expectations of a particular field or industry), decision making and reality orientation. Consequently, NADA's Career Counseling Model is intended to develop trainee's career maturity and have better vocational skills in the future. Thus, this paper is written to discuss the effectiveness of NADA's Career Counseling Model towards the level of career maturity among the trainees in the drug rehabilitation center.

\section{Methodology}

To answer the research questions, this research had applied a qualitative research approach. According to Creswell (2008), qualitative data is seen an as long and broad answer that allowed responded to share their opinion. The participants were involved with 10 sessions of group counseling which applying the Career Counseling Model conducted by facilitators (registered counselor). The qualitative data than obtained from the facilitator observation, semi-structured questions and in-depth interview sessions. The data collected were going to answer the research 
INTERNATIONAL JOURNAL OF ACADEMIC RESEARCH IN BUSINESS AND SOCIAL SCIENCES

Vol. 9, No. 6, June, 2019, E-ISSN: 2222-6990 C 2019 HRMARS

questions on Identify the Effectiveness of Career Counseling Model and it is emphasized on two independent variables which are the participant's self-concept and career maturity.

\section{Sampling Techniques}

This research had involved 22 participants who undergone treatment in rehabilitation centers knows as Rehabilitation center $A$. The participants were chosen based on a purposive sampling technique which certain criteria had been determined in choosing the participants. Chua Yan Piaw (2005) defines purposive sampling as a procedure of choosing a sample from selected criteria. The participants were chosen based on the range of age and duration staying in the current rehabilitation center.

\section{Instrumentation}

This study was carried out by using a research design that employed a qualitative approach which is the observation of facilitator, semi-structured questions and in-depth interview sessions. The observation of the facilitator will include the participants cognitive, behavior and emotion along the 10 sessions whereas the semi-structured questions and protocol questions for in-depth interview were developed by the researcher referring to the inventories of Career Maturity Inventory (CMI) and Tennessee Self-Concept Scale (TSCS) accordingly to the objectives of the study. The developed questions then being validated by the experts. The protocol questions for the semi-structured interview and in-depth interview are as follows:

Table 2: Semi-structured questions

\begin{tabular}{|c|c|l|}
\hline No & Theme & \multicolumn{1}{c|}{ Questions } \\
\hline 1 & $\begin{array}{c}\text { Self- } \\
\text { Concept }\end{array}$ & $\begin{array}{l}\text { Does this program help you to know yourself } \\
\text { better? (Explain how and why) }\end{array}$ \\
\hline 2 & $\begin{array}{c}\text { Career } \\
\text { planning }\end{array}$ & $\begin{array}{l}\text { Does this program help you in career decision } \\
\text { making? (Explain how and why) }\end{array}$ \\
\hline 3 & $\begin{array}{c}\text { Career } \\
\text { planning }\end{array}$ & $\begin{array}{l}\text { Does this program help you to gain information } \\
\text { regarding career opportunities? } \\
\text { (Explain how and why) }\end{array}$ \\
\hline 4 & $\begin{array}{c}\text { Career } \\
\text { planning }\end{array}$ & $\begin{array}{l}\text { Does this program help you to identify the } \\
\text { systematic strategy in career planning? (Explain } \\
\text { how and why) }\end{array}$ \\
\hline
\end{tabular}


INTERNATIONAL JOURNAL OF ACADEMIC RESEARCH IN BUSINESS AND SOCIAL SCIENCES Vol. 9, No. 6, June, 2019, E-ISSN: 2222-6990 @ 2019 HRMARS

Table 3: In-depth interview questions on Self-concept

\begin{tabular}{|l|l|}
\hline & \multicolumn{1}{|c|}{ SELF-CONCEPT } \\
\hline 1 & What do you think about your health? \\
\hline 2 & Are you considering yourself as a neat person? \\
\hline 3 & What is your opinion regarding the value of honesty? \\
\hline 4 & Are you a trustworthy person? \\
\hline 5 & Can you accept yourself as it is? \\
\hline 6 & How do you overcome your problem? \\
\hline 7 & Are you comfortable being alone? \\
\hline 8 & Can you engage with a new acquaintance? \\
\hline 9 & What is your education level? \\
\hline 10 & $\begin{array}{l}\text { Which one is your preference between academic or } \\
\text { vocational? }\end{array}$ \\
\hline
\end{tabular}

Table 4: In-depth interview questions on Career Maturity

\begin{tabular}{|l|l|}
\hline & \multicolumn{1}{|c|}{ CAREER MATURITY } \\
\hline 1 & What is your readiness in having a career? \\
\hline 2 & After undergoing the module, how is your knowledge of career? \\
\hline 3 & What is your score according to Self-directed search inventory? \\
\hline 4 & How is your career choice? \\
\hline 5 & Have you made your choice on your preference career? \\
\hline 6 & Is your career preference choice realistic? \\
\hline
\end{tabular}

\section{Research Procedure}

The researcher developed the protocol questions and was validate by the experts. After finish with the protocol question, the interview session is administered after the participant finished undergone the Career Counseling Model for 4 weeks ( 2 or 3 sessions per week). The interview sessions were recorded and being detailed transcripted later on. From the transcripted data, a thematic analysis will be applied. The analyzed data then being consolidated to identify the findings of this study. Figure 1 shows the illustration of the research procedure as below: 


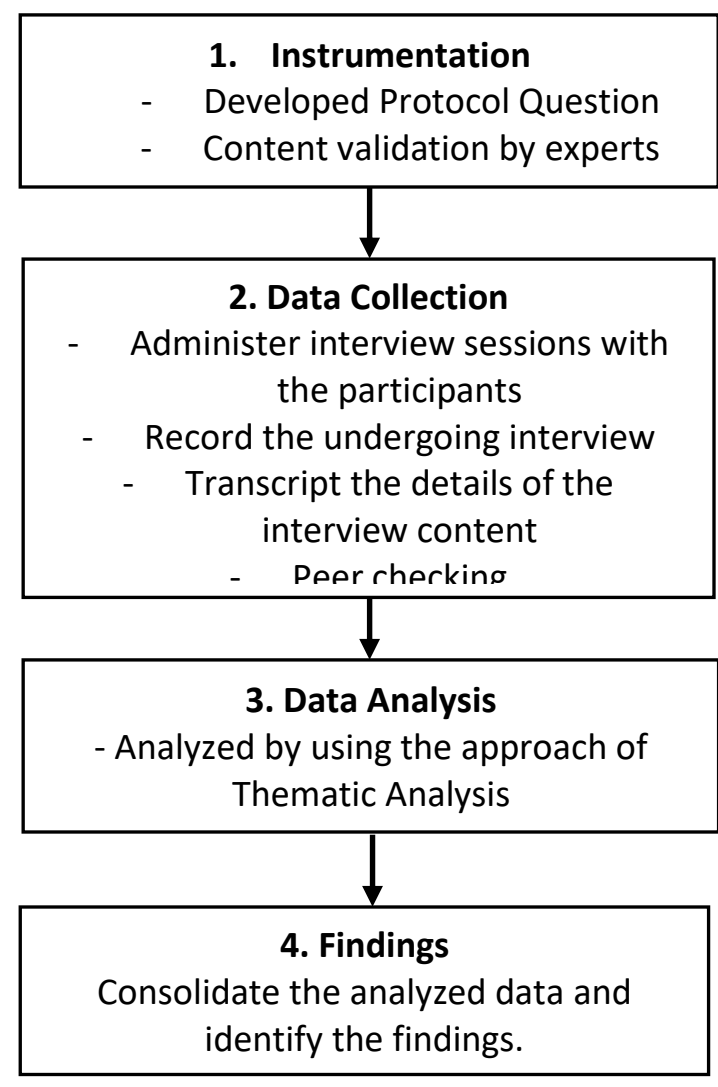

Figure 1: The illustration of the research procedure

\section{Data Analysis}

The collected data were managed and analyzed using a thematic analysis approach. According to Boyatzis (1998), the thematic analysis included 5 processes that are gathering data, coding data, code validation, themes or frameworks identification and information consolidation by finalizing theme names. The data was recorded and being transcript as written data. The researcher will be coding every two or three lines of text with handles that identify keywords, concepts, images, and reflections. Coding is an explicit and iterative process in which the researcher will alter and modify the analysis as reflected by the data and as ideas emerge. According to Boyatzis (1998) a "good code" is one that captures the qualitative richness of the phenomenon. The code should be clear and concise, clearly stating what it is, its boundaries and how to know it when it occurs.

The coded data is then being validated more than one researcher to ensure the integrity of the codes and to avoid misinterpreted and are free of researcher bias. The researchers then read and re-read the data, double-checking the codes for consistency and validation. The integration of the codes from the data becomes the codebook from which themes emerge. From the codebook, the researcher identifies themes and sub-themes which are the patterns have emerged from the coded 
INTERNATIONAL JOURNAL OF ACADEMIC RESEARCH IN BUSINESS AND SOCIAL SCIENCES

Vol. 9, No. 6, June, 2019, E-ISSN: 2222-6990 (C) 2019 HRMARS

data. The researcher finalizes the name of each theme, writes its description and illustrates it with a few quotations from the original text.

\section{Findings}

The findings displayed various opinion and respond on the implemented of Career Counseling Model which derived from the observation and reflection of the facilitator, semi-structured questions and in-depth interview. To answer the objective of the study, the qualitative data were categorized into two categories which are career maturity and self-concept. The following table is the illustration of the main themes collected from the in-depth interview sessions.

\begin{tabular}{|c|c|c|}
\hline \multirow{11}{*}{$\begin{array}{c}\text { NADA's Career Counseling } \\
\text { Model }\end{array}$} & THEMES & SUB-THEME \\
\hline & \multirow{5}{*}{ Self-concept } & Gain awareness about themselves \\
\hline & & Know more about themselves \\
\hline & & Aware of self-strengths and weaknesses \\
\hline & & Enhanced confident level \\
\hline & & Gained new knowledge \\
\hline & \multirow{5}{*}{ Career maturity } & $\begin{array}{l}\text { Get insight to plan a systematic and } \\
\text { realistic career planning }\end{array}$ \\
\hline & & $\begin{array}{l}\text { Aware of the preference and favorable } \\
\text { career }\end{array}$ \\
\hline & & Help to make a clear decision \\
\hline & & $\begin{array}{l}\text { Get new knowledge and insight for career } \\
\text { planning }\end{array}$ \\
\hline & & Get motivated \\
\hline
\end{tabular}

Table 3 Main themes highlighted from respondents

The following two sections discuss the response of the facilitators and participants on the Career Counseling Model.

\section{1) Research objective 1: To identify the effectiveness of Career Counseling Model towards the participant's Self-Concept}

There were 3 activities conducted applying the theme of self-concept which is icebreaking, selfconcept 1 and self-concept 2 . The first data was derived from the observation and reflection of the facilitator who conducted the group counseling sessions. The response from the observations of the facilitators are as follows:

\section{Facilitator observations and reflections.}

In activity 1 , most of the facilitator saying that the group participant was effective and dynamic even though some group reaches group dynamics a little bit late. The participation of the group members in the 
INTERNATIONAL JOURNAL OF ACADEMIC RESEARCH IN BUSINESS AND SOCIAL SCIENCES Vol. 9, No. 6, June, 2019, E-ISSN: 2222-6990 (C) 2019 HRMARS

counseling session was very helpful to ensure a positive first impression for the participants to maintain their commitment in the next session. The response from the facilitator are as follows:

"The activities can be carried out within the group as it is understandable for the participants. It is very important to ensure good perception on the first session for the group participants."

(Facilitator 1)

"The participants give very good participation within the group session as they listen and give their own response" (Facilitator 2)

Most of the facilitator saying that the groups' session reaching their dynamic in the first session. The rapport was essentially helping the process of career counseling in the group.

"Even though the session were a little passive, in the beginning, it reaches group dynamic easily as the group member starting to build the rapport within the group. (Facilitator 3 )

Most of the facilitator agree that the participant takes seriously about their discussion on drug history, family background, and life planning as the facilitator said:

" The participants discuss seriously their drug history and life planning in the future" (Facilitator 1)

The majority of the facilitator mentioned that the participants actively involved with the session and give them some insights. The facilitator said that:

"The participant said that they have to make preparations for their future life planning especially after being released from the rehabilitation center." (Facilitator 3 )

\section{Semi-structured questions}

Through semi-structured questions, the participants write their own answer subjectively. The objective of the self-concept sessions was to ensure the participants know about themselves more and to help the group members know each other well. Most of the participants saying that this 
INTERNATIONAL JOURNAL OF ACADEMIC RESEARCH IN BUSINESS AND SOCIAL SCIENCES Vol. 9, No. 6, June, 2019, E-ISSN: 2222-6990 (C) 2019 HRMARS

activity helps them gained awareness about themselves and know their group member, as well as they, said:

"I get to know more about myself, my own strength and weaknesses" (Participant 1)

"From this program, I get the chance to know about my friends more" (Participant 2)

"I can understand my friends more" (Participant 3)

The majority of them also saying that through the sessions they can share their weaknesses to the group members. Then the group members can share their opinions and suggestions to improve their weaknesses.

"Reprimand and advice from my friends about my behavior gives me awareness and insight to improve myself in the future" (Participant 4)

Some of the participants also admit that through this program they can realize their own strengths that they don't realize previously. As they said:

"From this program, I manage to understand my own strength that I don't even aware of them as my strengths." (Participant 5)

Overall, the activity carried out manage to achieved the main objective of this activity to create and build rapport between the participants in the group session.

\section{In-depth interview session.}

The data from in-depth interview had been transcripted and the codes were identified and sorted into the table below:

\begin{tabular}{|c|c|c|c|}
\hline Theme & No & Participant & Response \\
\hline \multirow{3}{*}{$\begin{array}{l}\text { Know more } \\
\text { about } \\
\text { themselves }\end{array}$} & 1 & Participant 1 & $\begin{array}{l}\text { After joining this program, I know about myself more. I also realized } \\
\text { that finally, I am capable to communicate well with other people, } \\
\text { especially during the group discussion. }\end{array}$ \\
\hline & 2 & Participant 5 & $\begin{array}{l}\text { This program helps to give me more ideas on how to know about } \\
\text { myself more. }\end{array}$ \\
\hline & 3 & Participant 6 & $\begin{array}{l}\text { This program helps me to identify my strengths and weaknesses so } \\
\text { that I can learn more about myself. }\end{array}$ \\
\hline \multirow{8}{*}{$\begin{array}{l}\text { Confident and } \\
\text { courage }\end{array}$} & 4 & Participant 2 & I feel more confident about myself \\
\hline & 5 & Participant 3 & This program helps build a good rapport between group members. \\
\hline & 6 & Participant 4 & $\begin{array}{l}\text { I feel confident to achieve what I had planned and I have more } \\
\text { courage after joining this session because this helps me to know } \\
\text { about myself more. }\end{array}$ \\
\hline & 7 & Participant 7 & $\begin{array}{l}\text { Honestly, I am a shy person prior. Thanks to this program, I learn to } \\
\text { start to communicate well in the group discussion. }\end{array}$ \\
\hline & 8 & Participant 8 & $\begin{array}{l}\text { After the session on knowing about ourselves, I started to accept } \\
\text { myself. }\end{array}$ \\
\hline & 9 & Participant 9 & $\begin{array}{l}\text { I know myself more after undergoing this program. The effect was } \\
\text { deep inside which it helps to increase my courage }\end{array}$ \\
\hline & 10 & Participant 10 & $\begin{array}{l}\text { Once I feel like I know myself more, I don't even care what people } \\
\text { say about me and currently, I feel more confident }\end{array}$ \\
\hline & 11 & Participant 11 & $\begin{array}{l}\text { I feel so relieved after doing sharing sessions with my groupmates } \\
\text { and feel more confident after realizing my own strengths. } \\
\text { Previously, those unspoken things were kept by myself }\end{array}$ \\
\hline
\end{tabular}


From the information given by the participants, the data were sorted as below:

a) Most of the participants saying that this model helps to increase their awareness about themselves, as the participants said:

"After joining this program, I feel like I know myself more than before. I also manage to identify my own weaknesses and strengths" (Participant 1)

"I know myself more after undergoing this program. The effect was deep inside which it helps to increase my courage. (Participant 9)

"This program helps me to identify my strengths and weaknesses so that I can learn more about myself." (Participant 6)

"Once I feel like I know myself more, I don't even care what people say about me and currently I feel more confident. (Participant 10)

b) Besides that, the participants also mentioned that this model enhanced their confidence level and courage to face their lives after being released from the rehabilitation center. The response is:

"Somehow I feel so confident to achieved what I planned and my courage is lifted after joining all the sessions" (Participant 1 )

"This program helps to enhance my confidence level. Previously I am a very shy person, but in group discussion, I learn how to communicate, give responds and opinion." (Participant 7) "I feel so relieved after doing sharing sessions with my groupmates and feel more confident after realizing my own strengths. Previously, those unspoken things were kept by myself (Participant 11)

c) Some participants also admit that they gained a lot of new knowledge from this program.

"This program helps to enhance my knowledge and give me insight. Especially the session on thought stopping. It really helps me to understand the way people behave from their way of thinking" (Participant 4)

"This program helps to improve my knowledge about the career. It helps me to able to have a better plan on my career path in the future. (Participant 8)

\section{2) Research objective 2: To identify the effectiveness of Career Counseling Model towards the participant's Career Maturity}

\section{a) Facilitator observations and reflections.}

The facilitator sees that activities are easily understood by the participants. However, there is also some difficulty for low-educated participants to answer the instruments given, due to terms they do not understand. The facilitator sees the participants respond well throughout the session and there is also a question-and-answer session throughout the activity as the facilitator said: 
INTERNATIONAL JOURNAL OF ACADEMIC RESEARCH IN BUSINESS AND SOCIAL SCIENCES

Vol. 9, No. 6, June, 2019, E-ISSN: 2222-6990 (C) 2019 HRMARS

"Participants respond well and active in question and answer session" (Facilitator 1)

"Participants are delighted to understand their personality and what work environment works best with their respective career options" (Facilitator 2)

"This model can help in building up the workforce to be chosen and the path in line with selfesteem and measured interest". (Facilitator 3)

"Participants are encouraged to give their views and questions about career choices among them" (Facilitator 2)

"Participants seem to be so immersed with the discussion on how to adapt to their career and eager to continue their working plan in the future" (Facilitator 1)

\section{b) Semi-structured questions}

Through semi-structured questions, the participants write their own answer subjectively. The objective of the career planning sessions was to ensure the participants to have a new view about the career pathway, getting new knowledge and opportunities for them after being released from the rehabilitation center. about themselves more and to help the group members know each other well. Most of the participants saying that this activity helps them gained new knowledge about themselves and know their group member, as well as they, said:

'I can see myself through this test'. (Participant 1)

'Show a favorable career and help to think about my career and career opportunities'. (Participant 2)

'Can make a decision in a favorable career and help to think about my career and career opportunities' (Participant 4)

'In the discussion, I started to think of what was good and appropriate for me' (Participant 5)

'I can make decisions on favorable workplaces, make career plans after leaving the center' (Participant 8)

'I can think about the job and career opportunities, although I feel so dark and narrow' (Participant 9)

'I know where the company or place I can find to get work later' (Participant 10) 
INTERNATIONAL JOURNAL OF ACADEMIC RESEARCH IN BUSINESS AND SOCIAL SCIENCES

Vol. 9, No. 6, June, 2019, E-ISSN: 2222-6990 (C) 2019 HRMARS

Overall, participants feel that this activity is able to achieve the objectives outlined, which is to enable participants to gain new insight and knowledge about their career planning afterward.

\section{c) In-depth Interview Session}

The second research objective aimed to identify the effectiveness of the Career Counseling Model towards the participant's Career Maturity. From the transcripted data, the codes were identified and sorted into the table below:

\begin{tabular}{|c|c|c|}
\hline Theme & Participant & Response \\
\hline \multirow{6}{*}{$\begin{array}{l}\text { Career } \\
\text { maturity }\end{array}$} & $\begin{array}{l}\text { Participant } \\
1\end{array}$ & After joining this program, my goal is clearer \\
\hline & $\begin{array}{l}\text { Participant } \\
2\end{array}$ & $\begin{array}{l}\text { I really feel R (Realistic) personality closely related } \\
\text { to myself. I do not like to mix with people. I really } \\
\text { like to do some work, which is important for me to } \\
\text { work }\end{array}$ \\
\hline & $\begin{array}{l}\text { Participant } \\
3\end{array}$ & $\begin{array}{l}\text { A lot of career information, in general, I get where } \\
\text { I know there are job opportunities that are } \\
\text { appropriate for ex-addicts, loans, and financial } \\
\text { resources. }\end{array}$ \\
\hline & $\begin{array}{l}\text { Participant } \\
4\end{array}$ & $\begin{array}{l}\text { This module helps me make more realistic career } \\
\text { decisions. }\end{array}$ \\
\hline & $\begin{array}{l}\text { Participant } \\
5\end{array}$ & The talks have been improving my motivation. \\
\hline & $\begin{array}{l}\text { Participant } \\
6\end{array}$ & $\begin{array}{l}\text { I feel more confident to carry out the career I have } \\
\text { planned now compared to previously I have an } \\
\text { unclear vision about my goals and career. }\end{array}$ \\
\hline
\end{tabular}

a) The participant said that it helps them to set their career plan more systematic and their live objectives become clearer as they said:

"After joining this program, my career goal becomes clearer" (Participant 1)

b) The participants also saying that they gained a lot of new knowledge and insights which include knowledge on career information and opportunities, career planning and selfmanagement. The participants said that:

"There are a lot of career information that I gained which include information on the suitable career for former drug addicts and financial source. I also gained very specific information on how to achieve my career goal" (Participant 2) 
INTERNATIONAL JOURNAL OF ACADEMIC RESEARCH IN BUSINESS AND SOCIAL SCIENCES

Vol. 9, No. 6, June, 2019, E-ISSN: 2222-6990 (C) 2019 HRMARS

Besides that, this model aids the participants to set up a realistic and systematic career planning in the future. The participants said that:

"This module helps me to set a realistic career planning" (Participant 4)

The participants agreed that they realized and aware of the importance of having a systematic career planning as they said:

"Having a systematic career planning helps me to make better and realistic planning. This is why realistic planning is important" (Participant 4)

\section{Discussion}

There are 9 activities executed aimed to help the participants getting to know about themselves better, awareness on their preference career and workplace environment, gained information on how to search for working opportunities and new information on having a systematic and realistic career planning. In short, 3 sessions executed focusing on the enhancement of participant's selfconcept and 6 activities to enhance the participant's career maturity. According to Savikas (1984), career maturity refers to one readiness to make a decision on career planning with equipped vocational skills and education development. In addition, career maturity is an individual's ability to make a realistic career choice, including the awareness of what is required to make career decisions and the extent of individual choices regarding any agencies inconsistent manner from time to time (Ohler, Levinsen \& Hays, 1996). To identify the effectiveness of the activities, the qualitative data and information were collected from facilitator's observation, semi-structured question, and in-depth interview sessions.

From the data collected, the respondents felt they know more about themselves and aware of their career and working preferences especially after taking the Self-directed Search (SDS). They admit that the SDS test can describe their personality and the appropriate field and work environment for them. For example, respondents stated that:

"SDS really helps me in getting to know myself and my career interests." (Participant 2)

Despite the SDS test, the activities in the module itself manage to help the participants to know more about themselves as they said:

"I get to know more about myself, my own strength and weaknesses" (Participant 1)

"From this program, I get the chance to know about my friends more" (Participant 2)

"I can understand my friends more" (Participant 3)

"Reprimand and advice from my friends about my behavior gives me awareness and insight to improve myself in the future" (Participant 4)

"From this program, I manage to understand my own strength that I don't even aware of them as my strengths." (Participant 5)

Super, Starishevsky, and Matlin (1963) have suggested that self-concept plays an important role in the formation of career development. They also mentioned that the growth of a person's knowledge and experience contributes to the complexity of his or her career self-concept. Research had been done by Samuel \& Samuel (1974) proves that a person with low self-concept is more likely to involved with drug addicts. Another research by Carmichael, Linn, Ted Pratt, and Webb (1977) 
also proves that a goal-oriented counseling rehabilitation treatments had positive effects on one's self-concepts that have misused substance abuse compared to those who did not undergo rehabilitation Thus, in the progress of helping the participants in making decision about their career, the enhancement of the participant's self-concept is significantly important to nurture the participant's career maturity.

The participants who underwent the third activity had admitted that this activity helps them to think about their career planning and career opportunities in the future. Overall, participants can understand career choices that are in line with interests and are realistic in accordance with the objectives outlined through this activity. For example, respondents stated:

"Before I join the program, I was always wondering about my future career and sometimes I don't even think much about my future career. Now, I can see more clearly on what to do after being relieved from the rehabilitation center "(Participant 4)

Respondents also noted that the activities in this model have helped them in gaining new information and make decision making. During the sharing from Jobs Malaysia talks, respondents said they had gained new information and where they would after being released from the rehabilitation center. For example, respondents stated that:

"Jobs Malaysia can help in terms of the channels they are looking for as I have a problem working for them before." (Participant 5)

"I can make decisions on favorable workplaces, make career plans after leaving the center" (Participant 8)

"The talks have been improving my motivation." (Participant 5)

"I feel more confident to carry out the career I have planned now compared to previously I have an unclear vision about my goals and career." (Participant 6)

Magnusson (1995) states that at this stage the participants are in the second (Exploration) and the third (Decision) stage. At the exploration stage, clients explore their own work experiences, skills, and interests. It aims to renew the enthusiasm and expectation of clients in finding appropriate careers. Indirectly the client has the opportunity to express something meaningful within them in the career planning process. At the third level is the client-level decision making. Decisions made reference to the appropriate job listings based on client experience and interests. Clients also need to identify appropriate careers based on their intuition. The counselor explores the perception of the client by using the 'what if' question technique in some of the listed job situations. This can help the client to make more informed decisions.

Besides that, this model seems to manage to help the participants to build a realistic plan of action for their career planning that they can use after being released from the rehabilitation center. For example, respondents stated:

"While making an action plan, the information I get from the talks and group discussions more specific about the career I'm interested in which helps me make a more realistic career decision. " (Participant 12)

This is in line with the fourth step (stage of preparation) and the fifth stage (implementation stage) based on the measures outlined by Magnusson (1995). At the stage of preparation, there are two key keys that should be focused on systematic planning in achieving the ultimate goal. One of them is to create a plan of action involving a contract between a counselor and a client that will detail 
the steps for the client, measure and evaluation or the planned timeline. Next, the participants need to improve their basic skills before entering their workplace. Several things need to be considered include work (job search), knowledge and education (learning skills, admission applications to educational institutions), and individual skills.

\section{Conclusion}

In conclusion, this study has proven the effectiveness of the Career Counseling Model toward the participant's career maturity and self-concept level. The collected data shows that more positive improvement in career maturity and self-concept of the participants after going through a full session of the Career Counseling Model. This explains the major improvement in clients' awareness, knowledge, and skills for career planning and also the enhancement of self-concept after undergoing this career model. The duration of the intervention sessions is recommended to be conducted consistently so that the nurturing process to all clients about the importance of having a career for life can be successfully accomplished. Through the findings obtained, this Career Counselling Model is provenly effective in the way of elevating the clients' career maturity and self-concept as so they will be able to restore their functions in society, thus becoming a fully functioning entity

\section{Acknowledgement}

It is to acknowledge that this paper is fully funded by National Anti-Drug Agency (NADA) in collaboration with researches from Asian Centre for Research on Drug Abuse, Universiti Sains Islam Malaysia.

\section{Corresponding Author:}

Amin Al Haadi Shafie, Email: amin@edu.usim.my

\section{References}

Boundy, D., \& Collelo, T. (2001). Preventing Relapse Among Inner-City Recovering Addict. Retrieved from Reelizations Media.

Boyatzis , R. E. (1998). Transforming Qualitative Information: Thematic analysis and code development. Sage.

Braun, V., \& Clarke, V. (2006). Using thematic analysis in psychology. Qualitative research in Psychology, 77-101.

Carmichael, J., Linn, M., Pratt, T., \& Webb, N. (1977). Self-concept and Substance Abuse Treatment. Comprehensive Psychiatry, 18(4), 357-362. doi:10.1016/0010-440X(77)90007-4

Chua, Y. P. (2006). Research Statistic. Shah Alam: McGraw-Hill Education.

Creswell, J. (2008). Education Research: Planning, Conducting and Evaluating Quantitative and Qualitative Research (3rd ed.). Upper Saddle River NJ: Pearson Education Inc.

Fauziah, I., \& Naresh, K. (2009). Factors Affecting Drug Relapse in Malaysia. Asian Social Science, 5(12), 37-44.

Fauziah, I., Bahaman, A. S., Mansor, A. T., \& Mohamad Shatar, S. (2012). Penagih dadah dan keadaan berisiko tinggi kembali relaps. Jurnal Sains Sosial dan Kemanusiaan, 38-49. 
INTERNATIONAL JOURNAL OF ACADEMIC RESEARCH IN BUSINESS AND SOCIAL SCIENCES

Vol. 9, No. 6, June, 2019, E-ISSN: 2222-6990 @ 2019 HRMARS

Henkel, D. (2011). Unemployment and Substance Use: A review of the literature. Current Drug Abuse Review, 4-27.

Kidd, J. (2007). Career Counseling: Handbook of Career Studies. SAGE Publications, Inc.

Magnusson, K. (1995). Five Processes of Career Planning. ERIC Clearinghouse on Counseling and Student Services.

McLellan, A. T., Lewis, D. C., \& O'Brien, C. P. (2000). Drug Dependence, a Chronic Medical Illness: Implications for Treatment, Insurance, and Outcomes Evaluation. Journal of the American Medical Association, 284(13), 1689-1695.

Myers, A. H., Baker, S. P., Li, G., Smith, G. S., Wiker, S., Liang, K. Y., \& Johnson, J. V. (1999). Back injury in municipal workers: A case-control study. American Journal of Public Health, 10361041.

O'Connell, T. S. (2001). Self-Concept: A Study of Outdoor Adventure Education with Adolescents. New York: New York University, School of Education.

Ohler , D. L., Levinson, E. M., \& Hays, G. M. (1996). The relationship between congruence, consistency, differentiation, and career maturity among individuals with and without learning disabilities. Journal of Employment Counseling, 33, 208-222.

Opp. (2007). Occupational Therapy. Retrieved from http://www.aota.org/AboutOccupationalTherapy/Professionals/MH/Articles/RecoveryWithPurpose.aspx

Platt, J. J. (1995). Vocational rehabilitation of drug abusers. Psychological Bulletin, 416.

Purkey, W. W. (1970). Self-Concept and School Achievement. Englewood Cliffs, NJ: Prentice-Hall.

Rabani Bavojdan, M., Towhidi, A., \& Rahmati, A. (2011). The relationship between mental health and general self-efficacy beliefs, coping strategies and locus of control in male drug abusers. Addict Health, 3(3 \& 4).

Rogers, C. R. (1951). On becoming a person: A therapist's view of psychotherapy. Boston: Houghton Mifflin.

Rushdi, A., Robson, N. Z., Muhammad M, A. Z., \& Mohamad, H. (2008). A fifty-year challenge in managing drug addiction in Malaysia.

Samuels, D., \& Samuels, M. (1974). Low Self-Concept as a Cause of Drug Abuse. Journal of Drug Education, 4(4), 421-438.

Savickas, M. L. (1984). Career maturity: The construct and its appraisal. Vocational Guidance Quarterly, 32, 222-231.

Super, D. (1984). Career and Life Development. San Francisco, CA: Jossey-Bass.

Super, D. E. (1953). A Theory of Vocational Development. American Psychologist, 30, 88-92.

Super, D. E. (1957). The Psychology of Careers. New York: Harper \& Row.

Wong, C. J., \& Silverman, K. (2007). Establishing and maintaining job skills and professional behaviors in chronically unemployed drug abusers. Substance Use \& Misuse, 1127-1140.

Zunker, V. G. (1986). Career Counseling: Applied Concepts of Life Planning (2nd ed.). California: Wadsworth, Inc. 